\title{
Research of the Theban limestone: the case of Temple of Hatshepsut in Deir el-Bahari
}

\author{
Teresa Dziedzic ${ }^{1, *}$, Mieczysław Michiewicz ${ }^{2, * *}$ \\ ${ }^{1}$ Wroclaw University of Science and Technology, 27 Wybrzeże Wyspiańskiego st., 50-370 Wrocław, \\ Poland \\ ${ }^{2}$ Rejtana st. 9a m.19, 02-516 Warszawa, Poland
}

\begin{abstract}
Authors of this article wish to collect previous research and broaden knowledge about limestone used for construction of the Temple of Hatshepsut and present results of the latest studies. The main purpose of the studies was to obtain information about tensile strength when bending architectural elements made of limestone. It will allow - among others the span of architraves on which vault blocks, architrave and ceiling slabs with cornices and railings to be established, as well as their acceptable strength parameters. Theban limestone research most often focuses on the geological origin of this material and its microscopic analysis. These tests are supplemented by endurance tests necessary for the work of engineers and architects who work on the reconstruction or exhibition of the ancient temples. The authors of many years of work in Polish - Egyptian Archeology - Conservation Mission at the Temple of Hatshepsut at Deir el-Bahari solve everyday problems associated with exposure and reconstruction of the monument.
\end{abstract}

From ancient times construction was based on materials available in the natural environment in a given region: stone, soil and wood. In Egypt from the times of the Old Kingdom the basic construction material besides dried brick was stone. Residential buildings of ordinary citizens, as well as royal palaces were made of dried brick, almost completely deprived of weather resistance. Therefore buildings constructed using this technique were destroyed, and researching them is rather difficult nowadays. In contrast to human habitations, temples were built of materials resistant to weather, such as stone. Limestone and sandstone in particular, were the most frequently used materials in construction of sacral buildings in Egypt.

New Kingdom limestone was very often used in construction. The Temple of Hatshepsut from the $15^{\text {th }}$ century BC was built of local materials - Theban limestone. Despite the fact that in the region of Thebes limestone is of poor quality and it is not suitable for construction purpose, there are two quarries; where materials were extracted in ancient times. The first one includes Hatshepsut's quarry close to the Valley of the Kings and the second one is located in Dababeya between Luxor and Essna. From these two quarries materials were extracted in ancient times [1]. There have been numerous articles

\footnotetext{
"Corresponding author: teresa.dziedzic@pwr.edu.pl; ${ }^{* *}$ m.michiewicz4@gmail.com
} 
written about Theban limestone, however their content mainly involves geological issues. Detailed and broad research of all types of stone applied in Egypt known in ancient times was conducted by R. and D. Klemm and included in the monography entitled Stones and quarries in ancient Egypt. Having conducted synthesis of literature regarding ancient quarries, as well as petrographic and physicochemical studies it can be concluded that the scope of the studies was rather extensive. Numerous research present the results of their studies regarding the construction of graves in Western Thebes. Research presented by Raphael A.J. Wüst and James McLane conducted in the grave of Sethy I in the Valley of the Kings deserves particular attention. These two scholars present among others results of mineralogical analysis, swelling tests and uniaxial compressive strength [2]. However, graves are similar to natural caves reaching deep underground. Their walls were cut in huge layers of the Theban mountains. The internal environment was closed with massive boulders for hundreds of years without ventilation, with stable weather conditions which contributed to nearly pristine preservation of the interior relief decoration. The case of temples built of stacked stone blocks exposed to weather conditions (mainly sun, temperature differences in the daily and annual cycles) is completely different. The structure or stability depended on the project, selection of stone and the experience of the architect or stonemasons [3]. Certainly these kinds of studies are very important, however for specialists conducting architectural research of ancient Egypt they are not sufficient. Only D. Arnold provides values of compressive strength and maximum load until the destruction of the material of selected rocks [4].

Table 1. Egyptian building stones and their properties. After Arnold [4] Table 2.1.

\begin{tabular}{|l|c|c|c|c|}
\hline & $\begin{array}{c}\text { Hardness } \\
\text { (MOH) }\end{array}$ & $\begin{array}{c}\text { Weight* } \\
\mathbf{( k g / l )}\end{array}$ & $\begin{array}{c}\text { Compressive } \\
\text { Strength } \\
\mathbf{( k g / q c m})\end{array}$ & $\begin{array}{c}\text { Strokes until } \\
\text { Destruction } \\
\text { (DIN 52107) }\end{array}$ \\
\hline Dense limestone & 4 & $2.65-2.85$ & $800-1,800$ & $8-10$ \\
\hline Porous limestone & & $1.7-2.6$ & $200-900$ & - \\
\hline Calcareous sandstone & & & & $5-10$ \\
\hline Nubian sandstone & -8 & $2.0-2.65$ & $300-1,800$ & $8-10$ \\
\hline Quartzite & $6-8$ & $2.6-2.8$ & $1,200-2,000$ & $10-12$ \\
\hline Alabaster (calcite) & $2-3$ & 2.7 & $1,600-2,400$ & $10-12$ \\
\hline Granite & $6-8$ & $2.6-3.2$ & $1,600-2,400$ & \\
\hline Aswan granite & & 2.679 & & $10-15$ \\
\hline Syenite & & $2.6-2.8$ & & $12-17$ \\
\hline Diorite & $5-6$ & $2.75-2.87$ & $1,700-3,000$ & \\
\hline Basalt & $6-8$ & $2.8-3.3$ & $2,500-4,000$ & \\
\hline Dolerite & & $2.93-3.05$ & & \\
\hline
\end{tabular}

*Specific gravity

\section{Limestone (Jnr hd "white stone")}

In ancient times rocks were divided into two categories: hard rocks and soft rocks. Hard rocks include ordinary igneous and metamorphic rocks. Soft rocks include usually sedimentary rocks [5]. Research indicates bedrock of $65 \%$ of the area extending from Asuan to the mouth of the Nile is made of limestone. Internal structures of particular segments of limestone, depending on the history of their appearance, have a different degree of resistance to atmospheric agents. The segments which are especially resistant include monadnocks on the slopes of wadis. It is therefore not extraordinary that the more 
resistant segments constituted the subject of interest of ancient builders of pyramids and temples. It is worth mentioning that quarries from the times of the pharaohs were exploited only to a certain level, which may indicate that only one layer was extracted. This can be observed when entering a quarry where monadnocks were preserved. In some cases the entire deposits were being extracted [6].

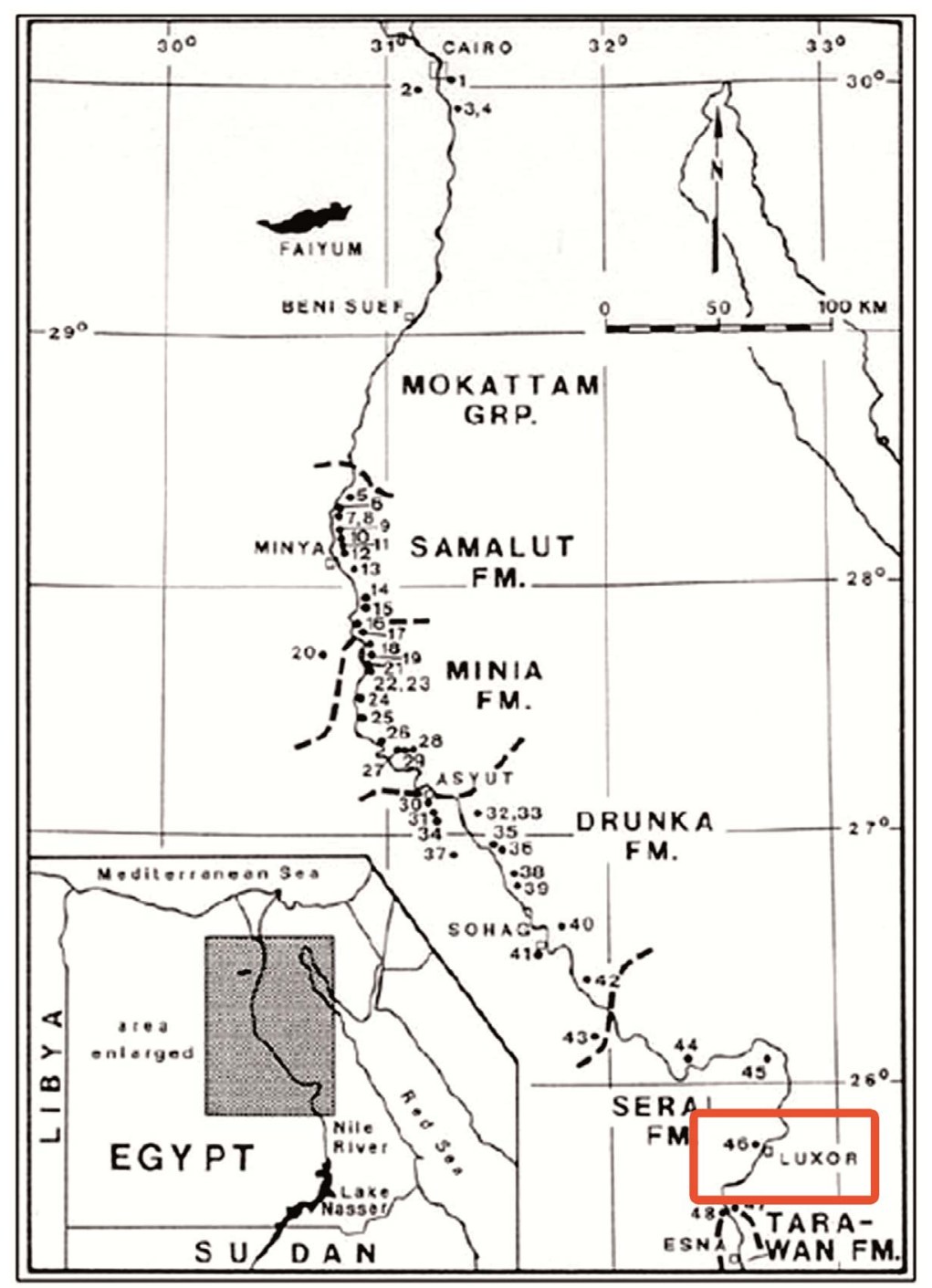

Fig. 1. Map of Egypt showing locations of ancient limestone quarries and formation contacts (heavy dashed lines). Adopted from J.A. Harrell and P. Storemyr [7].

The quarry from which the limestone for the construction of the Temple of Hatshepsut (the quarry of Hatshepsut and Amenhotep III) was extracted is situated $3 \mathrm{~km}$ from Qurna on the west bank of the Nile near Luxor, c. $500 \mathrm{~m}$ from the Valley of the Kings on the right side of the road leading to the royal necropolis (Geographical coordinates: $25^{\circ} 44.8^{\prime} \mathrm{N}$ $32^{\circ} 37.3 \mathrm{E}$ ). From the same quarry materials were used also during the region of Amenhotep III - extracted from his temple in West Thebes and later, during the reign of Merenptah for the construction of his temple [6]. 

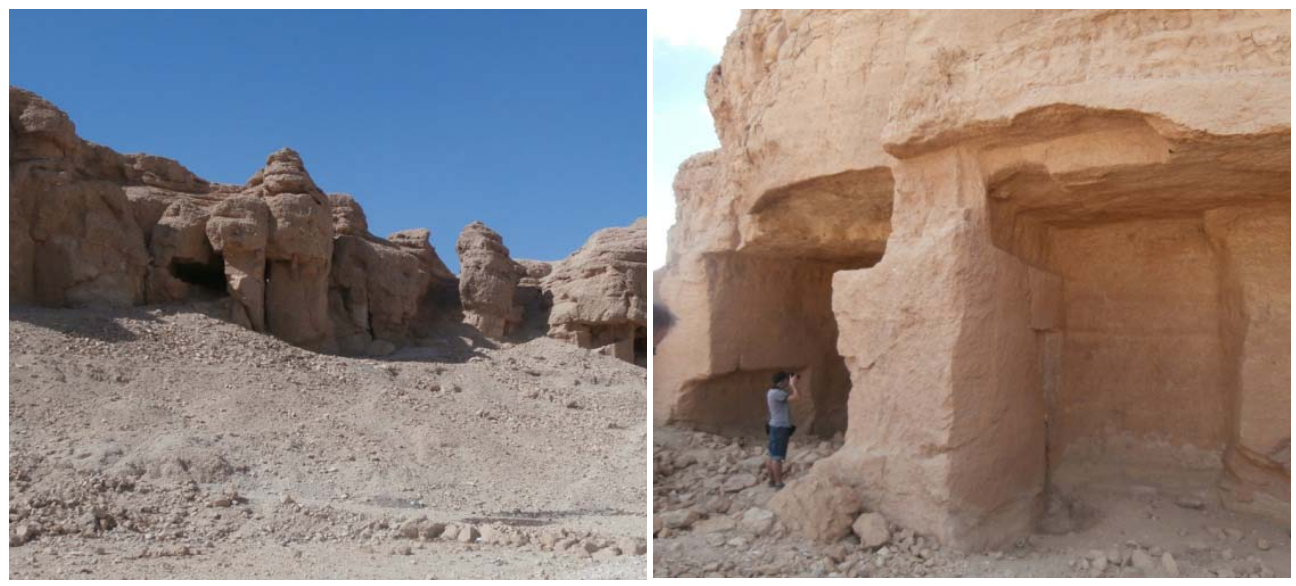

Fig. 2. The quarry of Hatszepsut. Photo by T. Dziedzic 2013.

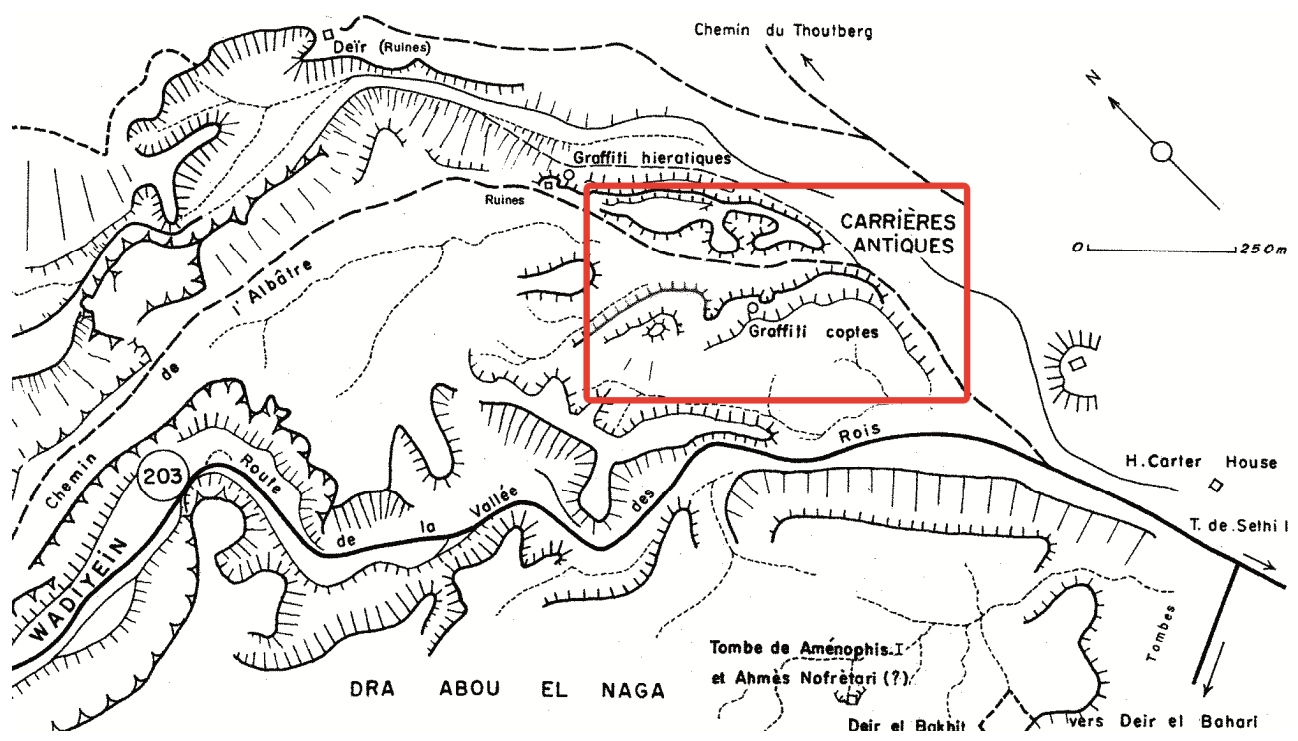

Fig. 3. Site plan. Adopted from Kurz [8].

The entire region consists of separate sedimentary rocks, Esna shale and Theban limestone, which came from 36-56 million years ago. The west bank and the surroundings of Luxor consist mainly of two layers. The thickness of the limestone formation is between 60-300 m. In 1960 Said identified Gebel Gurnah and defined its thickness for c. $300 \mathrm{~m}$. The spectacular view of these layers can be admired in Deir el-Bahari. Limestone consists chiefly of the mineral calcite, but it can also contain other constituents such as quartz, chert, clay, iron oxides, organics and dolomite. Limestones can be further divided into a soft limestone, which may also be called marly limestone, and a hard one. Marly limestone contains clay while the hard limestone has a crystalline structure [9]. 


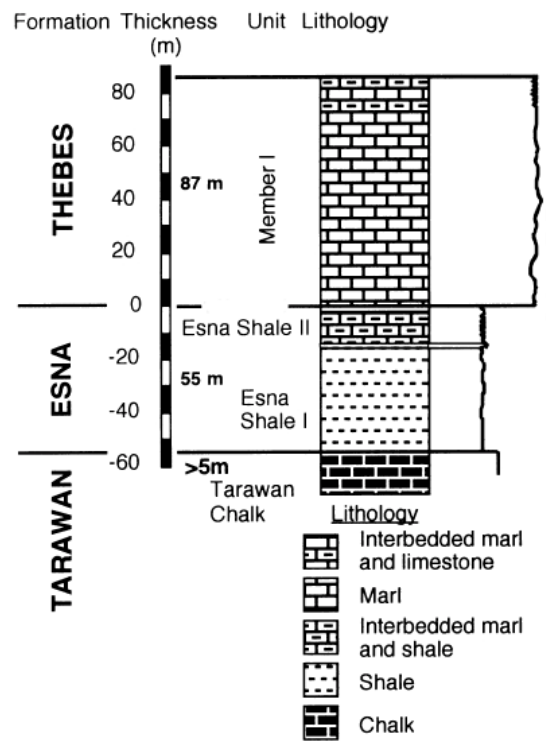

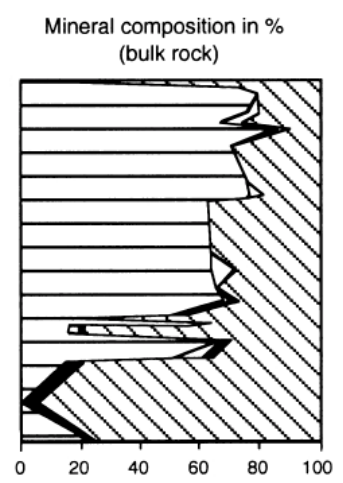
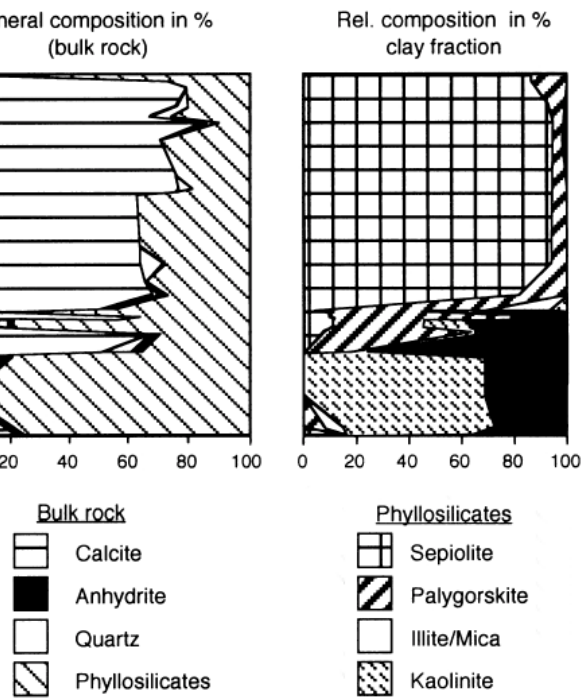

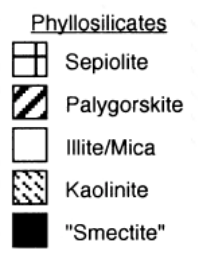

Fig. 4. Mineralogical composition of the Thebes and Esna Formation in the Gebel El Qurn area. Member I is mainly composed of marl and marl/limestone interbeds. The Esna Formation is divided into a lower (Esna Shale I ) and upper subunit (Esna Shale II ). The mineralogical composition of whole rock and clay mineral fraction is shown Adopted from R. A. J. Wüst, J. McLane [10].

Long-term research conducted by a Swiss mission in the temple of Merenptah in Gurnah made it possible to establish that numerous blocks discovered there are blocks which were earlier used in the temple of Amenhotep III and the temple of Hatshepsut. Results of research using the REM (Raster-Elektronen-Mikroskops) method published by H. Jaritz conducted on four collected samples present the arrangement of clay materials, micro fossils and salts, as well as diagenesis and weathering of the rock. Materials, structures and textures of the rocks were identified, and the quantitative share of elements in the rock (planimetric analysis) was determined. Stratigraphic research of the fossils of the rocks, geological field studies and lithostratigraphy in the analysed area indicated that the rocks are 53-46 million years old. All stratigraphic layers are arranged horizontally and they reach approximately $20 \mathrm{~m}$. The area of the quarry of Hatshepsut on the basis of sedimentological studies was identified as marine environment [11].

An extraordinarily interesting issue is addressed by Shin-ichi Nishimoto, Sakuji Yoshimura, and Jiro Kondo in their short report which documents and interprets signs and hieroglyphs found in the quarry of Amenhotep III (the northern part of the quarry). They establish the course of everyday work of a stonecutter, and reconstruct that some of the red lines define volume of a given block [12]. These studies are in progress and let us hope that they will be extended to the quarry of Hatshepsut.

In 2008 Maciej Pawlikowski conducted studies regarding the appearance of patina on the surface of limestone blocks in the temple and undertook an attempt to establish chronology of various elements of the building on the basis of these studies. The studies indicated that the rate of appearance of patina is not constant, therefore in some weather conditions patina appears slower, and in others - quicker. In his article he pays attention to the fact that probably also on the surface of one block over a long period of time weathering decreases. It may be connected - among others - with porosity, composition and size of stone grains, as well as climate variability. Limestones of the same Theban formation will weather at various rates at the same time [13]. 


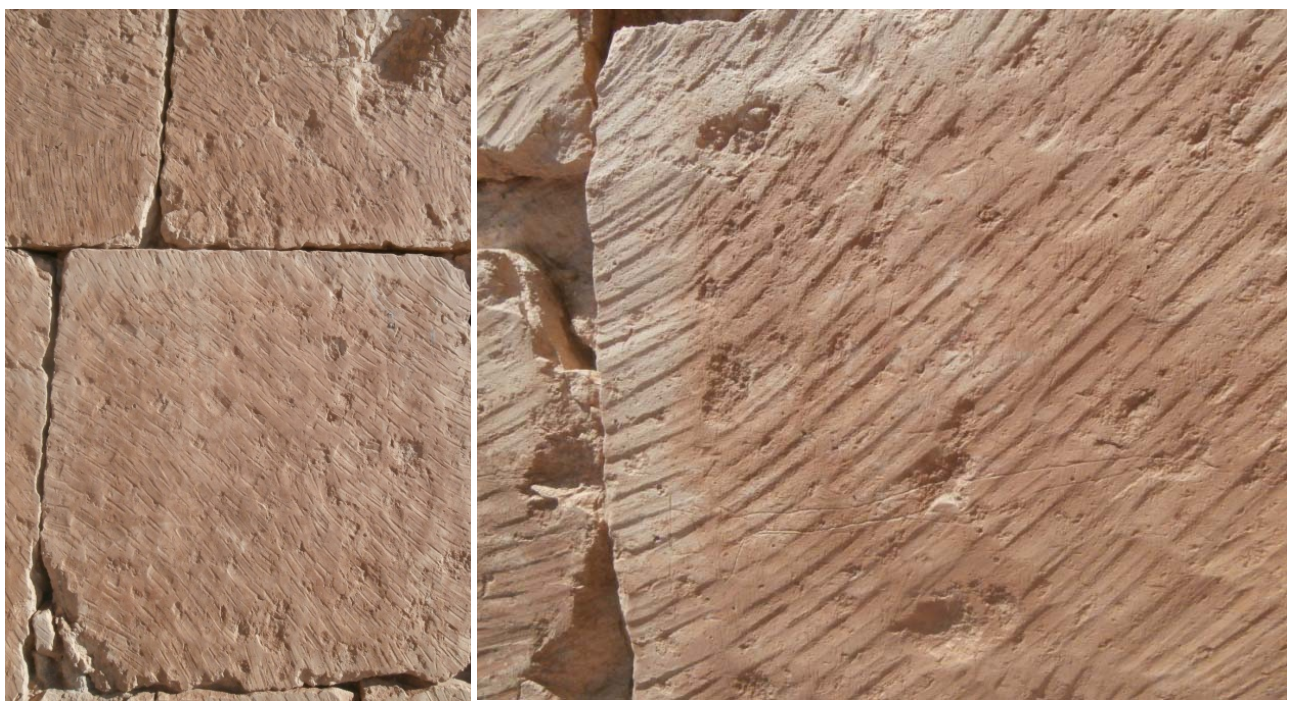

Fig. 5. Stone blocks from the walls of the temple of Hatshepsut. Photo by T. Dziedzic 2013.

\section{Limestone tensile strength}

The subject of the field studies was stone material of Theban limestone which came from local quarries and was used during the construction works of the temple of Hatshepsut. Research samples were obtained from fragments of historical blocks from the wall of the temple in its southern zone - the southern wall of the Royal Worship Complex. The purpose of the studies was to determine computational tensile strength during bending $\mathrm{f}_{\text {Rdt }}$ of the historical rock. The characteristics regarding the tensile strength of the material will be used for architectural studies when considering extreme spans of architraves loaded with stone ceiling panels of the temple. To conduct the field studies in Deir el-Bahari four samples of limestone $(20 \mathrm{~cm}$ long; cross-section $2.5 \times 2.0 \mathrm{~cm}$ ) were cut from damaged blocks of the temple walls.

\section{Research facility}

The facility to conduct research on the samples was constructed on a rigid wooden support (cross-section: $10 \times 10 \mathrm{~cm} ; 70 \mathrm{~cm}$ long) situated on levelled stone supports (axial spacing: $40 \mathrm{~cm})$. Supporting thresholds made of a steel rod $(\varnothing 6 \mathrm{~mm})$ were installed on the bar with the spacing of $15 \mathrm{~cm}$. One transverse slot for the unmovable support was grinded in each stone sample; the slots stabilized the elements during loading. On the upper surface of the samples shallow transverse slots were grinded in order to stabilize the "framework" aggravating the research samples. The aggravating "framework" was overhanging articulately on the research samples, and the liquid regulated load growth was implemented by controlled filling of a metal 15-liter container with water. The tarred "framework" with a constant weight was $15.0 \mathrm{~kg}(0.15 \mathrm{kN})$; it constituted preload and it was applied nondynamically. After approx. 10 minutes the load was increased by adding water to the metal container at a rate of 4 liters $/$ minute $(0.04 \mathrm{kN} / \mathrm{min})$. When the sample was broken, water was not added anymore. Precise measurement of the volume of water allowed the minimal strength breaking the sample to be established. The static strength analysis of the 
experiment's results allowed approximate strength and permissible tensile stress when bending historical limestone to be determined.

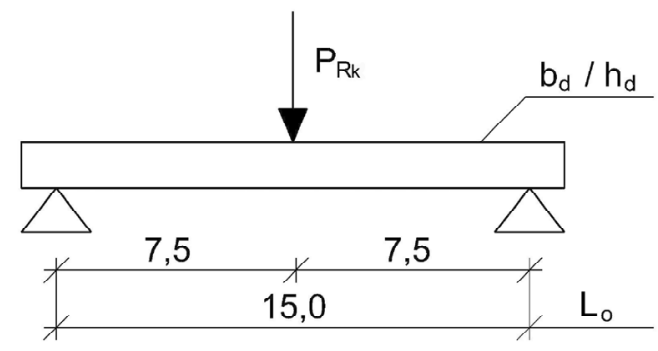

Fig. 6. Research scheme and assumptions for static strength analysis.

$\mathrm{P}_{\mathrm{Rk}}$ - the aggregated load of the bar - minimum breaking strength $[\mathrm{kN}]$,

$\mathrm{L}_{\mathrm{o}}$ - the span of bars in the axis of the supports $[\mathrm{cm}]$,

$b_{d}$ - nominal width of the bar $[\mathrm{cm}]$,

$\mathrm{h}_{\mathrm{d}}$ - nominal height of the bar $[\mathrm{cm}]$,

$\mathrm{x}$ - the number of limestone bars being the subject of research,

$\mathrm{W}_{\mathrm{x}}^{\mathrm{pl}}$ - plasticity index of the bar strength $=0.292 \mathrm{xb}_{\mathrm{d}} \mathrm{xh}_{\mathrm{d}}{ }^{2}\left[\mathrm{~cm}^{3}\right]$,

$\mathrm{M}_{\mathrm{Rk}}$ - breaking moment of the bended bar:

$$
\mathrm{M}_{\mathrm{Rk}}=0.5^{2} \times \mathrm{L}_{\mathrm{o}} \times \mathrm{P}_{\mathrm{Rk}}=3.75 \mathrm{P}_{\mathrm{Rk}}(\mathrm{kNcm}) \text {, }
$$

$f_{\text {Rkt }}{ }^{x}$ - breaking tensile stress when bending the bar $\mathrm{x}$ :

$$
\mathrm{f}_{\text {Rkt }}{ }^{\mathrm{x}}=10 \mathrm{M}_{\mathrm{Rd}}: \mathrm{W}_{\mathrm{x}}^{\mathrm{pl}}=128,4 \mathrm{P}_{\mathrm{Rk}}:\left(\mathrm{b}_{\mathrm{d}} \mathrm{x} \mathrm{h}_{\mathrm{d}}{ }^{2}\right)[\mathrm{MPa}]
$$

$f_{\text {Rkt }}$ - average breaking tensile stress :

$\mathrm{f}_{\text {Rdt }}=\sum \mathrm{f}_{\text {Rkt }}{ }^{\mathrm{x}}: \mathrm{x}(\mathrm{MPa})$

$$
\gamma_{p}-\text { safety factor for brittle fracture }-2.0
$$

$f_{\text {Rdt }}$ - computational tensile stress of the stone during bending:

$$
\mathrm{f}_{\mathrm{Rdt}}=\mathrm{f}_{\mathrm{Rkt}}: \gamma_{\mathrm{p}}=0.5 \mathrm{f}_{\mathrm{Rkt}}(\mathrm{MPa})
$$

\section{Static strength analysis of the field studies' results}

The results of the static strength analysis were presented in the table below.

\begin{tabular}{|c|c|c|c|c|c|c|c|c|}
\hline $\begin{array}{c}\text { Limestone } \\
\text { bar }\end{array}$ & $\begin{array}{r}\text { Cross } \\
\text { dime } \\
\text { Heigh }\end{array}$ & $\begin{array}{l}\text { ection } \\
\text { sions } \\
\text { Width }\end{array}$ & $\begin{array}{l}\text { Strength } \\
\text { index }\end{array}$ & $\begin{array}{l}\text { Load of } \\
\text { the bar }\end{array}$ & $\begin{array}{l}\text { Bending } \\
\text { moment }\end{array}$ & $\begin{array}{c}\text { Tensile } \\
\text { stress }\end{array}$ & $\begin{array}{c}\text { Average } \\
\text { tensile } \\
\text { stress }\end{array}$ & $\begin{array}{c}\text { Permissible } \\
\text { stress }\end{array}$ \\
\hline $\mathrm{x}$ & $\mathrm{h}_{\mathrm{d}}[\mathrm{cm}]$ & $\mathrm{b}_{\mathrm{d}}[\mathrm{cm}]$ & $\mathrm{W}_{\mathrm{x}}^{\mathrm{pl}}\left[\mathrm{cm}^{3}\right]$ & $\mathrm{P}_{\mathrm{Rk}}[\mathrm{kN}]$ & $\begin{array}{c}\mathrm{M}_{\mathrm{Rk}} \\
{[\mathrm{kNcm}\}}\end{array}$ & $\begin{array}{c}\mathrm{f}_{\mathrm{Rkt}}^{\mathrm{x}} \\
{[\mathrm{MPa}]}\end{array}$ & $\mathrm{f}_{\mathrm{Rkt}}[\mathrm{MPa}]$ & $\mathrm{f}_{\mathrm{Rdt}}[\mathrm{MPa}]$ \\
\hline 1 & 2.17 & 2.37 & 3.26 & 0.2368 & 0.888 & 2.724 & \multirow{4}{*}{2.95} & \multirow{4}{*}{1.48} \\
\hline 2 & 2.20 & 2.50 & 3.53 & 0.3188 & 1.196 & 3.388 & & \\
\hline 3 & 2.16 & 2.26 & 3.08 & 0.2398 & 0.899 & 2.919 & & \\
\hline 4 & 1.80 & 2.60 & 2.46 & 0.1815 & 0.681 & 2.768 & & \\
\hline
\end{tabular}

Table 2. Permissible tensile stress during bending $f_{\text {Rdt }}[\mathrm{MPa}]$ of Theban limestone established on the basis of the studies conducted on the samples obtained from original blocks from the temple of Hatshepsut in Deir el Bahari. M. Michiewicz. 


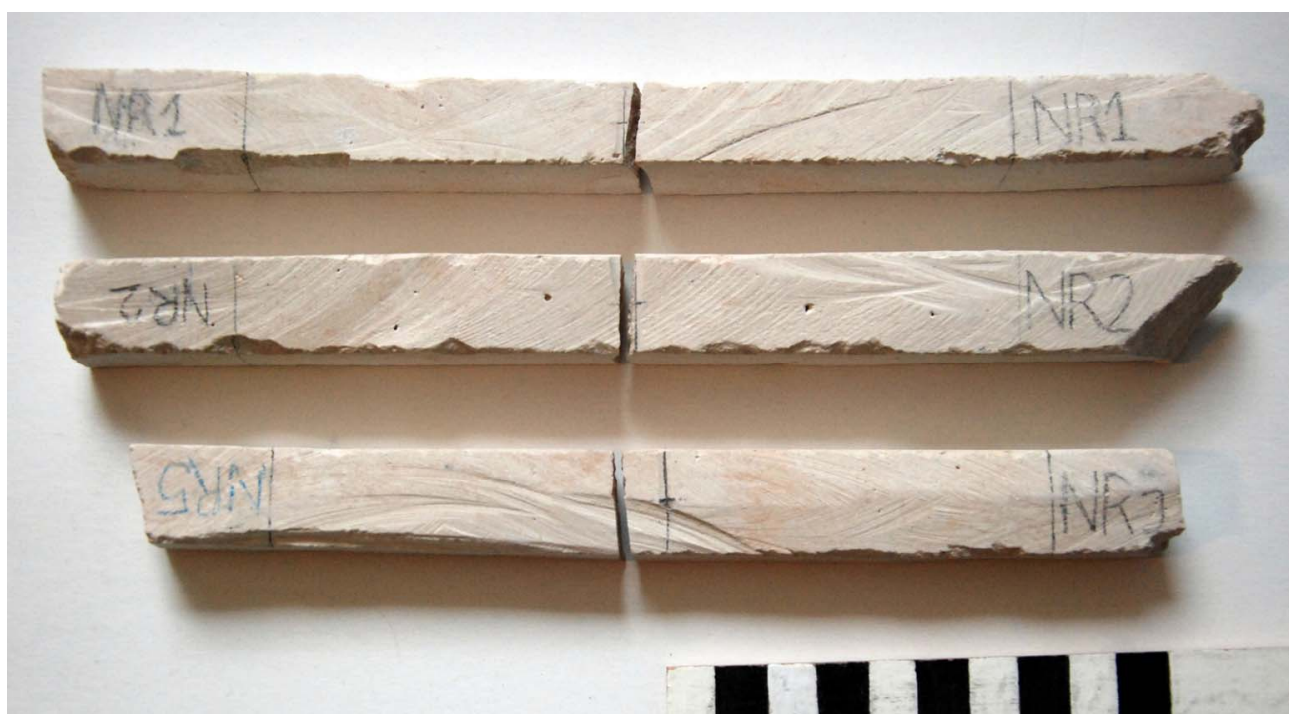

Fig. 7. Test samples after the test. Photo by T. Dziedzic 2014.

From the field studies it can be concluded that computational tensile stress when bending historical Theban limestone $\mathbf{f}_{\text {Rdt }}$ is assessed as $1.5 \mathrm{MPa}$, assuming the global safety factor for brittle fracture was $\gamma_{p}=2.0$.

The differences in strength of the samples being studied were not significant, therefore it is recommended to expand the studies and increase the quantity of research materials to at least 10 pieces with lager dimensions. The studies should be conducted in a professional strength laboratory.

\section{References}

1. A. Lucas, (Ancient Egyptian materials and industries, 54,1962)

2. R. A. J. Wüst, J. McLane,(Rock deterioration in the Royal Tomb of Seti I, Valley of the Kings, Luxor, Egypt [in:] EG 58, 175-178, 2000)

3. M.-P. Aubry, W.A. Berggren, Ch. Dupuis, H. Ghaly, D. Ward, Ch. King, R. W. O. Knox, K. Ouda, M. Youssef and W. F. Galal, (Pharaonic necrostratigraphy: a review of geological and archaeological studies in the Theban Necropolis, Luxor, West Bank, Egypt TN 21, 241, 2009)

4. D. Arnold Building in Egypt. (Pharaonic stone masonry, 28, 1991)

5. E. Bloxam 2010, (Quarrying and Mining (Stone). In Willeke Wendrich (ed.), UCLA, 2 (2010)

6. R. Klemm and D. Klemm, (Stones and quarries in ancient Egypt, 23, 135 (2008)

7. J.A. Harrell and P. Storemyr, (Ancient Egyptian quarries - an illustrated overview [in] N. Abu-Jaber, E. G. Bloxam, P. Degryse and T. Heldal (eds.) (QuarryScapes: ancient stone quarry landscapes in the Eastern Mediterranean, GS,12, 18, 2009)

8. M. Kurz, (Graffiti de la montagne Thébaine II, 6, pl 215, 1977)

9. Ö. Aydan, H. Tano, M. Geniş, I. Sakamato, M. Hamada, S. Yoshimura, (Environmental and rock mechanics investigations for the restoration of tomb of Amenophis III. Egypt Joint Symposium New Horizons [in] GGEGE, 152, 244, 2008) 
10. R. A. J. Wüst, J. McLane Rock deterioration in the Royal Tomb of Seti, I, Valley of the Kings, Luxor, Egypt [in:] EG 58, 178, 2000)

11. H. Jaritz, (Untersuchungen im Totentempel des Merenptah in Theban [in:] ÄBA 16, 2527, 1997)

12. S. Nishimoto, S. Yoshimura, J. Kondo, (Hieratic Inscriptions from the Quarry at Qurna in interim Report, [in] BMSAES I, 20-22, 2002)

13. M. Pawlikowski, (Examination of the patina coating of natural Theban limstones as well as blocks of Hatshepsut Temple, Upper Egypt [in:] AS in Archaeology, 9, 2008) 